\title{
ELECTROLYTES - SODIUM, POTASSIUM AND CHLORIDES IN POULTRY NUTRITION
}

\author{
Milica Živkov Baloš ${ }^{\star}$, Sandra Jakšić, Slobodan Knežević, Miloš Kapetanov \\ Scientific veterinary institute "Novi Sad", Novi Sad
}

\begin{abstract}
Sodium, potassium and chlorides play a crucial role in maintaining body acid-base balance as well as osmotic pressure in body fluids. These processes are the result of synergetic action of all three elements, and the role of each individual component is difficult to define without knowing and taking into consideration the other two elements. The maintenance of this value is determined by three major factors - balance and ratio of electrolytes in feed, endogenous acid production and level of renal activity. Electrolyte imbalance is quite rare, since body's buffering system provides maintenance of normal physiological $\mathrm{pH}$ value. This article will give an overview of the role, importance and needs of poultry for sodium, potassium and chlorides, as well as occurrences related to deficit and the imbalance of those elements in feed.
\end{abstract}

Key words: sodium, potassium, chlorides, poultry

\section{ELEKTROLITI - NATRIJUM, KALIJUM I HLORIDI U ISHRANI ŽIVINE}

Milica Živkov Baloš, Sandra Jakšić, Slobodan Knežević, Miloš Kapetanov

Naučni institute za veterinarstvo "Novi Sad", Novi Sad

\section{Kratak sadržaj:}

Natrijum, kalijum i hloridi imaju ključnu ulogu u odražavanju acidobazne ravnoteže u organizmu i osmotskog pritiska u telesnim tečnostima. Ovi elementi deluju zajednički i vrlo je teško definisati ulogu svakog

${ }^{1}$ Corresponding author: milica@niv.ns.ac.rs 
pojedinačno, bez poznavanja uloge ostala dva. Održavanje acido-bazne ravnoteže je pod uticajem tri najvažnija činioca: balansa i odnosa elektrolita $\mathrm{u}$ hrani, endogene produkcije kiselina i nivoa renalne aktivnosti. Debalans elektrolita je retka pojava, pošto puferni sistem organizma obezbeđuje održavanje normalne, fiziološke $\mathrm{pH}$ vrednosti, međutim kada do njega dođe mogu nastati značajne ekonomske štete u živinarskoj proizvodnji. U ovom radu biće opisani uloga, značaj i potrebe živine za natrijumom, kalijumom i hloridima, kao i pojave vezano za deficit i debalans navedenih elemenata u hrani.

Ključne reči: natrijum, kalijum, hloridi, živina

\section{INTRODUCTION}

While requirements for sodium, potassium and chlorides have been clearly definied, there is currently an understanding of the need to achieve a balance between cation and anion supply (Leeson and Summers, 2001). Most commonly, the electrolyte balance is described by a simple formula $\mathrm{Na}+\mathrm{K}-\mathrm{Cl}$ and expressed as $\mathrm{mEq} / \mathrm{kg}$ meal. The amount $250 \mathrm{mEq} / \mathrm{kg}$ is considered optimal for normal physiological function. Electrolyte imbalance is quite rare, since body's buffering system provides maintenance of normal physiological $\mathrm{pH}$ value. The maintenance of this value is determined by three major factors - balance and ratio of electrolytes in feed, endogenous acid production and level of renal activity. Electrolyte balance formula designated by Mongin (1981) is as following:

$\mathrm{Na}+\mathrm{K}-\mathrm{Cl}$ in feed $=$ feed cations - anions + endogenous acids + excess base

Feed anion balance value other than $250 \mathrm{mEq} / \mathrm{kg}$ feed results in acidosis or alkalosis, which causes both production and health problems. Supplementation of $\mathrm{Na}$ (without $\mathrm{Cl}^{-}$) in feed leads to an increase in concentration of $\mathrm{HCO} 3-$ ions and elevated blood $\mathrm{pH}$, whereas supplementation of $\mathrm{Cl}^{-}$(without $\mathrm{Na}$ ) decreases concentration of $\mathrm{HCO} 3-$ ions and $\mathrm{pH}$ value. Endogenous acid production affects the electrolyte balance. It changes also with the change of protein source in feed, that is, replacement of soybean meal with fish meal results in modification of electrolyte balance from 17.4 to $12.1 \mathrm{mEq} / \mathrm{kg}$ feed (Mongin, 1981). Anion imbalance can be solved by bicarbonate supplementation in the diet. The same author recommends that fishmeal-based poultry diets should be supplemented with sulfates to ensure electrolyte balance. The use of some divalent ions can interfere with electrolyte balance. Thus, supplementation of calcium chloride $(\mathrm{CaCl} 2)$ in the diet can induce acidosis in poultry, contrary to chloride sources such as $\mathrm{NaCl}$ and $\mathrm{KCl}$, which are associated with acidosis to a much lesser extent. This is due to the fact that calcium absorption from $\mathrm{CaCl} 2$ 
is lower than that of sodium from $\mathrm{NaCl}$. Calcium bounds to carbonates from $\mathrm{CaCO} 3$ using up bicarbonates from blood, and excessive unabsorbed chlorine causes acidosis.

Some exams of electrolyte imbalance include tibial dyschondroplasia and respiratory alkalosis. Tibial dyschondroplasia in chicks can occur as the consequence of electrolytic misbalance. The condition is associated with a range of factors including administration of $\mathrm{NH} 4 \mathrm{Cl}$ in feed production (Leeson and Summers, 2001).

Respiratory alkalosis occurs at high temperatures consequent to excessive loss of carbon-dioxide induced by panting. The condition can result in poor growth rate in meat industry and poor quality of eggshell that quite often affects highly-productive laying hens. Acid-base balance substantially affects the process of eggshell formation. The acid-base status of the intrauterine extracellular fluid strongly affects calcium solubility (precipitation); however, its influence on bicarbonate flows is still unclear. In normal conditions, the process of eggshell formation induces renal acidosis as a result of total reabsorption of filtrated bicarbonates. Concurrently, metabolic acidosis due to formation of insoluble $\mathrm{CaCO} 3$ occurs, since calcium ion $\left(\mathrm{Ca}^{++}\right)$pushes out the hydrogen ion $\left(\mathrm{H}^{+}\right)$from $\mathrm{HCO}^{-}$. Hydrogen ions induce elevation of $\mathrm{pH}$ value, and the balance is established in intrauterine extracellular fluid through the influence of bicarbonate from body's buffer system. Such acidosis is considered normal. Metabolic competition for $\mathrm{HCO}^{-}$ion that plays a role in both maintenance of acid-base balance and the process of eggshell formation induces severe acidosis, which results in reduced production of the eggshell. Moreover, feed supplementation with $\mathrm{NH} 4 \mathrm{Cl}$ can produce severe acidosis. In normal production conditions, substitution of $\mathrm{NaCl}$ portion with $\mathrm{NaHCO} 3$ can positively affect the eggshell formation process. In conditions of commercial egg production, maintenance of electrolytic balance by adding electrolytes in the feed should be avoided (Kapetanov et al., 2015).

Broilers and layers differ in their requirements and reactions to electrolyte therapy in conditions of heat stress. Thus, treatment with aqueous electrolyte solutions positively affects the growth rate and decreases the mortality in broilers. Whiting et al. (1991) reported that positive effects of electrolyte supplementation in drinking water for broilers during heat stress are attributed to the increased water intake rather than to anion/cation status in the electrolyte supplement itself.

It should be emphasized that exposure of poultry to high temperatures should be prevented because the blood bicarbonate levels decrease in such conditions, while extreme conditions may induce metabolic acidosis. The poul- 
try tolerates stable high temperatures much better than sudden temperature changes (increase or cyclic temperature challenge) (Kohne and Jones, 1975).

Electrolyte balance can affect the metabolism of numerous amino acids, especially lysine and methionine. It is well established that deficit of potassium in feed induces increased lysine accumulation in tissues. The accumulation rate correlates with potassium level. Such conditions of potassium deficiency result in decreased growth rate in chicks. High levels of sodium chloride, regardless of amino-acid balance, negatively affect the growth rate in poultry. It is likely that negative effects of electrolyte disbalance are more pronounced when using low-protein diet, since nitrogen turnover imbalance represents more serious problem (Leeson and Summers, 2001).

Electrolyte imbalance can be prevented by balancing anion and cation contents in poultry feed formulations. Thus, wheat has better electrolyte balance than maize, whereas soybean and other protein feeds have very low electrolyte balance due to high potassium content. Electrolyte balance should be taken into consideration when changing the protein source in the diet. Feed formulations with low electrolyte balance strongly require electrolyte supplementation (NaHCO3). Also, the problem of electrolyte imbalance is of importance in conditions when feed contains excessive sulfur or chloride. Balancing the electrolytes in feed by adjusting the cation concentration is very difficult if the feed contains high level of chlorides. Decrease of chloride level is feasible, as signs of chloride deficiency occur only when its level drops below $0.10 \%$. A portion of sodium chloride can be substituted with sodium-carbonate, bearing in mind the minimum requirements for chlorides that have to be satisfied.

\section{SODIUM (Na)}

Sodium is the major cation in extracellular fluid and essential element for normal life cycle and metabolism of both plants and animals. Sodium makes some $93 \%$ of the total cation content in blood plasma (Leeson and Summers, 2001). Its crucial role has first been established as early as in 1881 . Sodium is the basic constituent of salt, and all animals manifest strong need for salt.

Physiological role of sodium. Basic physiological functions of sodium are the following:

- participation in the maintenance of acid-base balance and optimal osmotic relationships;

- participation in the regulation of body fluid volume;

- participation in muscle cell contractions;

- close relation with adrenal gland functions; 
- playing a role in carbohydrate absorption, that is, energy turnover in the body

Sodium content in poultry ranges averagely from 0.1 to $0.14 \%$ of body mass. Some $30-40 \%$ of sodium is found in the skeleton, tightly bound to the inorganic part of the bone, thus being hardly available for satisfying animal's needs. Since contained mainly in blood plasma, the element can hardly be found in blood cells. This is the reason why it is considered the most important cation responsible for maintenance of $\mathrm{pH}$ in blood plasma. Sodium content in blood plasma of chickens is $8.4 \mathrm{mg} / \mathrm{ml}$ (Leeson and Summers, 2001), that is, $122-160 \mathrm{mmol} / \mathrm{l}$ in chickens and $145-147 \mathrm{mmol} / \mathrm{l}$ in turkey poults (Puls, 1990).

Sodium absorption and homeostasis. Sodium salts manifest ability to accumulate in the body by decreasing the excretion in conditions of low salt intake. Moderate increase in sodium intake is not considered big problem in poultry having in mind that concentration of this element in the water is not particularly high. With high sodium levels in the diet, the poultry will increase the water intake and remove excess sodium from the body via body excreta. The symptoms of toxicities will not manifest as long as birds have enough drinking water. However, in case of the intake of excess water, the symptoms of water toxicity will occur. On the other hand, substantial negative loss of water is associated with sodium deficit, where spending of accumulated extracellular fluid leads to severe dehydration of the birds.

Poultry diet is hypotonic in view of sodium content, yet it provides maintenance of stable concentration of the element in the body regardless of variable intake. Since homeostatic processes in blood and entire body are crucial for good health, all living organisms have developed a range of mechanisms for their maintenance.

Sodium is readily absorbed from small intestines, while certain amount is absorbed in the stomach. Some $85-90 \%$ of dietary sodium is excreted in the urine in the form of phosphates or chlorides (Jovanović et al., 2001).

Sodium metabolism. Activation of the majority of mitochondrial enzymes is mediated by intracellular ions of potassium and magnesium, whereas extracellular sodium ions $\left(\mathrm{Na}^{+}\right)$inhibit the activity of mitochondrial enzymes. A range of anions such as proteins, tricarboxylic acid, organic phosphates, glycerophosphates and keratin-phosphates, bicarbonates and some chloride ions are present in muscle and tissue cells. Some anions manifest ability to diffuse across cell membranes, while some are fixed to cytoplasmic structures or otherwise prevented to move and leave the cell. Such ions electrostatically attract 
cations including sodium. Together with potassium and anions, sodium forms buffer that is crucial for maintaining optimal $\mathrm{pH}$ value of the cytoplasm. Upon the entry of sodium and potassium into the cell, the accumulation of potassium ions is much higher than that of sodium ions.

Active transport of sodium and potassium ions is of vital physiological importance. More than one third of adenosine triphosphate (ATP) consumed by a resting animal is used for active transport of sodium and potassium (Leeson and Summers, 2001). Adenosine triphosphates are enzymes hydrolyzing ATR in the presence of sodium and potassium together with magnesium ions. By breaking ATR, the enzymes provide energy for active ion transport and pump three sodium ions out of the cell.

Sodium deficiency. Sodium deficiency results in decrease in osmotic pressure and consequent disturbance of acid-base balance. Symptoms of pronounced sodium deficiency include heart failure, decreased blood pressure, increased hematocrit and decreased elasticity of subcutaneous tissue as well as low adrenal gland function leading to elevated levels of uric acid in the blood and subsequent shock and death.

Less pronounced sodium deficiency in chickens causes poor growth, soft bones, corneal keratinization and decreased blood plasma volume. In laying hens, the symptoms mainly include decreased egg production, impaired growth and sometimes even cannibalism. A range of diseases are associated with vast excretion of sodium from the body, diarrhea and other gastrointestinal disorders or urinary losses consequent to renal failure or adrenal gland insufficiency. Poultry diet with sodium content below $0.012-0.050 \%$ is considered sodium-deficient (Puls, 1990).

Excess sodium. Sodium content in poultry feed at levels above $0.5 \%$ is considered toxic. Even dietary sodium contents of some $0.35 \%$ stimulate increased water intake in poultry, thus causing electrolyte imbalance, and elevated sodium levels result in water toxicity. Excess of dietary sodium in laying hens (above $0.19 \%$ of feed mix) causes decreased egg fertility (Puls, 1990) and poor quality of the eggshell (Leeson and Summers, 2001). Ducks are particularly sensitive to increased sodium content in the diet.

Sodium requirements for poultry. Sodium requirements for young birds are $0.15 \%$ of feed, provided that the level of chlorides is the same. For laying hens, the recommended levels range from $0.17-0.19 \%$. The ratio of sodium and chloride levels in poultry diet should be $1: 1$.

Introduction of nipple drinkers to poultry farms revealed that poultry consume inadequate amount of water because of anatomic incapability/limitation or lethargy, thus, the requirements for sodium are increased. In that respect, 
Murakami et al. (1997) recommend $0.25 \%$ sodium content in formulations for 21-day broilers. Linear relationship between growth rate and dietary sodium level for young poultry has been established, and the limit is commonly determined by manure consistency.

Sodium sources. Feeds of animal origin are particularly rich in sodium, as it is present in almost all tissues. Feeds of plant origin contain significantly lower sodium levels, and its content varies depending on numerous factors. Sodium content in grains ranges from $80 \mathrm{mg} / \mathrm{kg}$ in maize to over $500 \mathrm{mg} / \mathrm{kg}$ in oat grain, the contents in oilseed range $150-170 \mathrm{mg} / \mathrm{kg}$ and in wheat bran around $250 \mathrm{mg} / \mathrm{kg}$ (Živkov-Baloš et al., 1999). Kitchen salt/animal salt $(\mathrm{NaCl})$ is the major sodium source containing some $38 \%$ sodium. As high levels of salt result in increased water consumption, a portion of dietary salt (30\%) can be replaced with sodium bicarbonate without negative effects to production performance of poultry (Jovanović et al.,2001). In such cases, somewhat dry droppings can be observed.

\section{POTASSIUM (K)}

Potassium is the third most abundant element found in the body of most animals (NRC, 2005). Contrary to sodium, potassium is found in the body, that is, inside the cell itself. Blood cell level of potassium is somewhat 25 times higher than that of plasma cells. High potassium contents are characteristic for muscle and nerve cells, being some $4 \mathrm{mg} / \mathrm{kg}$ in muscles as compared to $0.1 \mathrm{mg} /$ $\mathrm{ml}$ in blood plasma (Leeson and Summers, 2001).

Physiological role of potassium. The functional role of potassium is similar to that of sodium; however, its activity is taking place inside the cell. The most important roles of potassium include:

- participation in the maintenance of acid-base balance and optimal osmotic relationships;

- activation of the range of intracellular enzymes;

- participation in protein and carbohydrate metabolism;

- playing essential role in preserving normal heart function as it decreases the contractility of cardiac musculature and favors heart muscle relaxation;

- increasing the permeability of cell membrane;

- promoting the absorption of free neutral amino acids such as glycine

Potassium metabolism and deficiency. The major manifestation of potassium deficiency (hypokalemia) includes generalized muscle weakness with subsequent limb weakness, decreased intestinal tonus associated with disten- 
sion, cardiac insufficiency as well as respiratory insufficiency and failure. Hypokalemia can occur consequent to severe stress. Stress conditions are associated with an increase of plasma proteins, which triggers adrenalin-mediated renal excretion of potassium into the urine. Upon reestablishment of glycogen stores, potassium returns to the liver. This can temporarily postpone hypokalemia. In the period of adaptation to stress, blood flow to the muscle gradually improves and lost potassium content is reestablished.

Low levels of dietary protein combined with low potassium levels or during fasting period result in poor growth of animals, yet without apparent manifestation of potassium deficiency. This is due to the fact that potassium produced by decomposition of tissue proteins compensates the deficit of dietary potassium, i.e., potassium excreted in the urine. In such instances, the potassium contents in feed can be reduced.

Potassium to nitrogen ratio in muscles and urine is relatively stable, thus, these two elements are released simultaneously during the process of bodytissue decomposition. Supplementation of proteins to poultry diet lacking nitrogen will cause increase in blood nitrogen level, but the birds will most probably manifest symptoms of hypokalemia. The lack of potassium results in decrease of tissue levels of neutral amino acids, whereas the content of basic amino acids increases in order to compensate potassium deficit. Thus, the consequences of excess lysine in feed can successfully be prevented through potassium supplementation in feed. Potassium is absorbed in the small intestines and eliminated in the urine.

Excess potassium. Potassium toxicities in healthy animals is rare. This is due to the body's ability to readily excrete potassium as well as regulate absorption. The major causes of hyperkalemia are excessive potassium intake, reduced renal losses, and redistribution of potassium (NRC, 2005). Teeter and Smith (1986) conducted a set of experiments and found no adverse effects when potassium (as $\mathrm{KCl}$ ) was supplied in water with corn-soybean base diet containing 7,300 $\mathrm{mg} \mathrm{K} / \mathrm{kg}$ when fed to week-old chicken pullets for two weeks under near optimal environmental conditions. Under heat stress conditions, offering water with 1,000 to $1,500 \mathrm{mg} \mathrm{K} / \mathrm{L}$ resulted in improved average daily gain in broilers, but blood $\mathrm{pH}$ and feed efficiency were not improved.

Smith et al. (2000) reported that the increase in the dietary concentration of potassium from 2,300 to $20,000 \mathrm{mg} / \mathrm{kg}$ caused a linear increase in water intake, water to feed ratio, and excreta moisture of layers.

Potassium requirements for poultry. Potassium deficiency is rarely observed in practice since standard poultry feed mixes contain more than $1 \% \mathrm{~K}$ (Puls, 1990) and feed with $0.1 \% \mathrm{~K}$ is considered potassium-deficient. 
Potassium contents in feed should range between 0.4 and $0.6 \%$ of feed mix. Nutritional recommendations depend on the age of poultry (Table1). Puls (1990) indicated that potassium requirements increase for $63 \%$ in conditions of an increase of ambient temperature from $24^{\circ} \mathrm{C}$ to $35^{\circ} \mathrm{C}$.

Potassium level in the body correlates with muscle mass, so it is used to calculate the body mass in vivo applying radioactive isotope of potassium $\mathrm{K} 40$, since ratio of $\mathrm{K} 40$ and total $\mathrm{K}$ is constant (Jovanović et al., 2001).

Table 1. Potassium requirements for poultry (Puls, 1990)

\begin{tabular}{cc}
\hline Age (weeks) & Requirements (\% K in dry matter) \\
\hline $0-2$ & 0.40 \\
$2-4$ & 0.30 \\
$4-8$ & 0.23 \\
$8-18$ & 0.10 \\
Layers & 0.10 \\
Turkeys - all ages & 0.40 \\
\hline
\end{tabular}

Potassium sources. Feeds of plant origin are rich in potassium, thus, supplementation is not necessary. Živkov-Baloš et al. (1999) reported potassium levels in maize, wheat and sunflower meal being 2,500-2,800 mg/Kg, 3,500 $\mathrm{mg} / \mathrm{Kg}$ and 13,850 $\mathrm{mg} / \mathrm{Kg}$, respectively.

\section{CHLORIDES ( $\left.\mathrm{Cl}^{-}\right)$}

Major part of chlorine, that is, chloride is found in extracellular fluids but also in red blood cells and other tissues. The elements are absorbed in small intestines; excess chloride is eliminated in the urine and is usually associated with excess sodium and potassium.

Physiological role of chlorides. Though closely associated with sodium, chlorides have some distinct independent functions such as:

- Chlorine is major anion of gastric juice and builds up gastric acid together with hydrogen ion;

- It participates in carbon-dioxide transport in the blood thus increasing plasma bicarbonate content

Chloride Metabolism and deficiency. Chloride ions have weak affinity of binding to protein ions, and enter the cell together with potassium. Chlorides are actively transported particularly via the cells of gastric mucosa. Chloride 
deficiency in chickens is associated with extremely poor growth, limb weakness, poor bone mineralization, high mortality rate, dehydration and high blood levels of chlorides as well as tetany-like neural symptoms. Feeds containing less than $0.05 \%$ sodium chloride $(0.03 \%$ chlorine) are considered chloride-deficient. Deficiency occurs more commonly in herbivores, since forage and grains are relatively poor in salt.

Chloride requirements for poultry. Chloride contents for poultry have to be balanced according to the requirements and/or potassium and sodium levels in the diet. Basically, the concentration of chlorides in the feed should be for some $10-15 \%$ higher than that of sodium.

Minimum chloride requirements for maximal growth rate of chickens are $0.13 \%$ and for turkey poults $0.10 \%$. Optimal levels for chickens and turkey poults are $0.30 \%(0.20-0.40 \%)$ and $0.25 \%$, respectively, whereas optimal level for turkeys is $0.27 \%$ (Puls, 1990).

Adequate dietary chlorides are of utmost importance for laying hens, as it prevents feather picking and cannibalism. Elimination of chlorides from layers' feed results in laying pause for 14-21 days. Returning of salt into diet results in accomplishment of $80 \%$ production peak within 16 days.

Excess chloride. Excess salt in drinking water manifests more severe toxic effects as compared with feed. Water with total soluble matter content higher than $3,000 \mathrm{mg} / \mathrm{l}$ is not appropriate for use in poultry industry. Tolerable chloride levels in water range from 0.015 to $0.018 \%$ ( 0.25 to $0.30 \%$ salt), whereas levels higher than $0.033 \%$ chloride (more than $0.54 \%$ salt) are considered toxic (Puls, 1990). In young growing birds, $2.7 \%$ salt in the diet, lead to rapid mortality (Morrison et al., 1975).

Tolerable salt levels in chicken feed are $0.9 \%$ chlorine (1.2\% salt), and for layer hens $1.2 \%$ chlorine (2\% salt) (Puls, 1990). Turkey poults are less tolerable to high salt contents in feed. Scrivner (1946) found that $1 \%$ sodium chloride in the feed for turkey poults was without effect, whereas $1 \%$ salt in the drinking water resulted in $100 \%$ mortality (within 48 hours) characterized by edema and ascites. Ducks tolerate excess chloride better than other domestic poultry. Dietary salt levels above $1 \%$ result in increased water content in the feces.

Excess chlorides in poultry feed leads to wet feces, extreme water consumption, ascites, edema, reduced thickness and hardness of the eggshell. The study of Smith et al. (2000) demonstrates that for every $0.25 \%$ increase in sodium chloride content of the diet there will be an additional $9 \mathrm{~g}$ water excreted per $\mathrm{g}$ of feces.

Chloride sources. Feed formulations based on maize and soybeans are very poor sources of natural sodium chloride. Supplementation of fishmeal 
into the feed reduces the requirements for salt. Major source of chlorides in animal feed is animal salt or kitchen salt.

\section{CONCLUSION}

Sodium, potassium and chlorides play a crucial role in maintaining body acid-base balance as well as osmotic pressure in body fluids. These processes are the result of synergetic action of all three elements, and the role of each individual component is difficult to define without knowing and taking into consideration the other two elements. Based on data presented in this paper the biological role of these three elements in normal metabolism during production of poultry is essential. Sodium, potassium and chlorides are a relatively nontoxic elements that is required in relatively large amounts to sustain life. Disturbances in metabolism can result in they being toxic. However, a combination of relevant quality control programs in the animal feed industry, as well as the implementation of good manufacturing practices and adequate education nutritionists can significantly reduce the risks associated with the appearance of electrolytic imbalance and toxicities.

\section{AKNOWLEDGMETS}

The presented work is part of the research done in the project TR31084 granted by the Serbian Ministry of Education, Science and Technological Development.

\section{REFERENCES}

1. Jovanović R., Dujić D., Glamočić D.: Ishrana domaćih životinja, 2. izmenjeno i dopunjeno izdanje, Stylos-Izdavaštvo, Novi Sad, 2001.

2. Kapetanov M., Pajić M., Ljubojević D., Pelić M.: Heat stress in poultry industry. Arhiv veterinarske medicine, 8, 2, 87 - 101, 2015.

3. Kohne H.J., Jones J.E.: Acid-base balance, plasma electrolytes and production performance of adult turkey hens under conditions of increasing ambient temperature. Poultry. Sci., 54, 2038-2045, 1975.

4. Leeson S., Summers J.D.: Scott's nutrition of the chicken. Chapter 5 - Minerals. 4th edition. Published by University books, Guelph, Ontario, Canada, 341-363, 2001.

5. Mongin P.: Recent advances in dietary anion/cation balance in poultry. Recent Adv. Anim. Nutr., 109-119, 1981. 
6. Morrison W.D., Ferguson A.E., Pettit J.R., Cunnigham D.C.: The effects of elevated levels of sodium chloride on ascites and related problems in turkeys. Poult. Sci., 54. 146-154, 1975.

7. Murakami A.E.: Estimation of the sodium and chloride requirements for the young broiler chick. J. Appl. Poultry Res., 6, 155-162, 1997.

8. National Research Council (NRC): Mineral tolerance of animals. Second revised edition, Committee on minerals and toxic substances in diets and water for animals, Board on agriculture and natural resources, Division on earth and life studies. National Academy Press, Washington D.C., 2005.

9. Puls R.: Mineral levels in animal health. Diagnostic data. Published by Sherpa International, Clearbrook, British Columbia, Canada, 1990.

10. Scrivner L.H.: Experimental edema and ascites in poults. J. Am. Vet. Med. Assoc., 108, 27-32, 1946.

11. Smith A.S., Rose R.G. Wells, Pirgozliev V.: Effect of excess dietary sodium, potassium, calcium, and phosphorus on excreta moisture of laying hens. Br. Poult. Sci., 41, 598-607, 2000.

12. Teeter R.G., Smith M.O.: High chronic ambient temperature stress effects on broiler acid-base balance and their response to supplemental ammonium chloride, potassium chloride, and potassium carbonate. Poult. Sci., 65, 1777-1781, 1986.

13. Whiting T.S., Andrews L.D., Stamps L.: Effects of sodium bicarbonate and potassium chloride drinking water supplementation. Poultry Sci., 70, 5359, 1991.

14. Živkov-Baloš M., Mihaljev Ž., Mašić Z.: Količine makro i mikroelemenata u hranivima sa područja Vojvodine. Savremena poljoprivreda, 1-2, 285288, 1999.

Primljeno: 20.09.2016.

Odobreno: 05.10.2016. 